\title{
Purification and characterization of angiotensin-I-converting enzyme inhibitory peptides isolated from whey proteins of milk fermented with Lactobacillus plantarum QS670
}

Yanan Xia, Jiaqi Yu, Weihan Xu, (1) and Quan Shuang* ()

College of Food Science and Engineering, Inner Mongolia Agricultural University, Hohhot 010018, China

\begin{abstract}
An angiotensin-converting enzyme inhibitory (ACEI) peptide with a median inhibitory concentration $\left(\mathrm{IC}_{50}\right)$ of $1.26 \mathrm{mg} / \mathrm{mL}$ was purified from whey proteins resulting from a fermentation using Lactobacillus plantarum QS670. The peptide was subsequently derived from an $\alpha_{S 1}$-casein, $\kappa$-casein, $\beta$-lactoglobulin, or serum albumin fraction. Analysis via liquid chromatography tandem mass spectrometry indicated that it had an amino acid sequence of Gly-Ala (GA). The GA dipeptide was also synthesized using an Fmoc solid-phase method. The GA dipeptide exhibited an $\mathrm{IC}_{50}$ of $1.22 \mathrm{mg} / \mathrm{mL}$ and was shown to be stable across both temperature (20 to $60^{\circ} \mathrm{C}$ ) and $\mathrm{pH}$ (2 to 12 ). Digestive enzymes including pepsin, trypsin, and chymotrypsin had negligible effects on activity. The whey exerted hypotensive effects when fed to spontaneously hypertensive rats (SHR), which exhibited a blood pressure drop of $2.33 \mathrm{kPa}$. A 4 -wk gavage treatment resulted in greater decreases of $7.46 \mathrm{kPa}$. Results of this study indicate that milk fermented using $L b$. plantarum QS306 has potential to be used as a functional food to help prevent or reduce hypertension-associated diseases.
\end{abstract}

Key words: Lactobacillus plantarum QS670, ACE inhibition peptides, purification, characterization

\section{INTRODUCTION}

Hypertension, a common chronic disease, is a major risk factor for cardiovascular diseases and death around the world (Timón et al., 2019). Nearly 9 million deaths are attributable to high blood pressure every year, and it is estimated that one-third of the general Western population has potential for hypertension symptoms (Zafari et al., 2017).

Received September 16, 2019.

Accepted January 27, 2020.

*Corresponding author: 18047124962@163.com
Angiotensin-converting enzymes (ACE), also called excitation peptidases II, are ideal targets in the treatment of hypertension and other cardiovascular diseases (Nakamura et al., 1995). Angiotensin-converting enzyme inhibitory (ACEI) peptides exert blood pressure-lowering activities (Kumar and Yin, 2018). These compounds have different amino acid sequences and chain lengths, but all have the ability to lower blood pressure (Ehlers and Riordan, 1989; Galli et al., 2019). Several chemical ACE inhibitors, including lisinopril, enalapril, and captopril, have been synthesized and currently serve as antihypertensive drugs. These inhibitors, however, have been shown to exert various side effects on patients, including abnormal taste, skin rashes, and coughing. These deleterious effects have prompted the development of natural, safe, and novel ACEI foods (Minervini et al., 2003; Zhao et al., 2019).

Recently, reports on bioactive natural ACE inhibitors isolated from food sources, such as turtle egg white, sweet potato, soybean, and milk have been reported (Seppo et al., 2003; Daliri et al., 2018). Fermented dairy products produced with Lactobacillus delbrueckii, Lactobacillus helveticus, Lactobacillus bulgaricus, Streptococcus salivarius, and Streptococcus thermophilus have also been reported to be rich in bioactive peptides that could control hypertension (Esmaeili et al., 2018; Usui et al., 2018). Recently Wu et al. (2019) isolated and identified an ACEI peptide (LPYPY) from milk fermented using Lb. delbrueckii QS306. Yang et al. (2015) used an arginine linker to join the ACEI peptides coding sequences from TFP and YFP, which were expressed in Lactobacillus plantarum (NC8) by an inducible vector pSIP-409. Chaves-López et al. (2014) evaluated mixed cultures of selected yeasts and lactic acid bacteria for their proteolytic activity and ability to produce fermented milk enriched with ACEI peptides. These authors reported that a combination of Pichia kudriavzevii, Lb. plantarum, and Enterobacter faecalis showed the highest ACEI activity.

In a previous study (Shuang et al., 2017), fermented milk using Lb. plantarum QS670 was shown having potential to lower blood pressure in hypertensive rats. 
The aim of the present study was to isolate and identify an ACEI peptide from milk fermented with $L b$. plantarum QS670 and to elucidate its characteristics by in vitro synthesis, to provide evidence that it could be used as ingredient in future functional foods to prevent chronic diseases.

\section{MATERIALS AND METHODS}

\section{Bacterial Strain}

Lactobacillus plantarum QS670 was initially isolated from a traditional cottage cheese fermentation and was provided by the Ethnic Food Development Team of the College of Food Science and Engineering, Inner Mongolia Agricultural University (Hohhot, China). The strain was stored in $40 \%$ glycerol at $-80^{\circ} \mathrm{C}$.

\section{Cultivation of Strains and Preparation of $p H$ 4.6 Extract}

Lactobacillus plantarum QS670 was serially cultured $(3$ passages $\times 24 \mathrm{~h})$ in de Man, Rogosa, and Sharpe medium (MRS; Guangdong Huankai Microbial Sci. and Tech. Co. Ltd., Guangzhou, China) at $37^{\circ} \mathrm{C}$. The pellet (following centrifugation at $3,000 \times g$ for $15 \mathrm{~min}$ at $4^{\circ} \mathrm{C}$ ) from the final broth culture was suspended in sterile saline $(0.9 \%)$ water $\left(10^{8} \mathrm{cfu} / \mathrm{mL}\right)$. A $3 \%$ inoculum (vol/vol) was added to sterile reconstituted skim milk powder $(11 \%, \mathrm{w} / \mathrm{vol})$ and incubated at $37^{\circ} \mathrm{C}$ for 48 h. Following fermentation the $\mathrm{pH}$ was adjusted to 4.6 (casein isoelectric point) with $1 \mathrm{M} \mathrm{NaOH}$, and the solution was centrifuged $\left(3,000 \times g\right.$ for $10 \mathrm{~min}$ at $\left.4^{\circ} \mathrm{C}\right)$. The resultant supernatant, referred to as supernatant 1 , was adjusted to $\mathrm{pH} 8.3$ with $1 \mathrm{M} \mathrm{NaOH}$ and centrifuged $\left(3,000 \times g, 5\right.$ min at $\left.4^{\circ} \mathrm{C}\right)$, and the supernatant was collected for ACEI peptide isolation (stored at $4^{\circ} \mathrm{C}$ ).

\section{ACEl Activity}

Angiotensin-converting enzyme inhibitory activity was determined using the method of Cushman and Cheung (1971) with some modifications. The treated samples were centrifuged $(3,000 \times g$ for $10 \mathrm{~min})$, and the supernatants $(0.8 \mathrm{~mL})$ were transferred to $1-\mathrm{mL}$ centrifuge tubes. Up to $200 \mu \mathrm{L}$ of $\mathrm{HCl}(1 \mathrm{M})$, samples, and ultrapure water, respectively, were added to a $37^{\circ} \mathrm{C}$ reaction system after $10 \mu \mathrm{L}$ of $0.1 \mathrm{U} / \mathrm{mL}$ of the $\mathrm{ACE}$ enzyme solution (EC 3.4.15.1, from rabbit lung) was added to initiate the reaction; then the reaction system was preincubated for $3 \mathrm{~min}$ at $37^{\circ} \mathrm{C}$. Thereafter, $80 \mu \mathrm{L}$ of hippuryl-L-histidyl-L-leucine (HHL, $5 \mathrm{mM}$, SigmaAldrich, St. Louis, MO) was added to the solution and incubated for $60 \mathrm{~min}$ at $37^{\circ} \mathrm{C}$. The enzyme reaction was terminated by adding $200 \mu \mathrm{L}$ of $\mathrm{HCl}(1 \mathrm{M})$, and the sample was cooled naturally to room temperature. Hippuric acid was extracted using ethyl acetate (1.2 $\mathrm{mL}$ ), heat-evaporated at $50^{\circ} \mathrm{C}$ for $100 \mathrm{~min}$, dissolved in distilled water, and evaluated spectrophotometrically at $228 \mathrm{~nm}$. The activity of each sample was tested in triplicate:

$$
\mathrm{ACEI} \text { rate }(\%)=(\mathrm{Aa}-\mathrm{Ab}) /(\mathrm{Aa}-\mathrm{Ac}) \times 100,
$$

where Aa is the absorbance without sample (buffer only), $\mathrm{Ab}$ is the absorbance in the presence of both $\mathrm{ACE}$ and sample, and Ac is the absorbance of the blank.

Inhibitory activity was expressed as the percent of $\mathrm{ACE}$ inhibition at a given peptide nitrogen concentration and as the peptide concentration required to inhibit $50 \%$ of the original $\mathrm{ACE}$ activity $\left(\mathbf{I C}_{50}\right)$. Results are expressed as averages of 3 determinations \pm standard deviation (SD).

\section{Peptide Concentration}

The peptide concentration was estimated by measuring the free amino group content with ortho-phthaldialdehyde (OPA) according to the methods described by Tsai et al. (2006). The OPA concentration was calculated compared with a standard tyrosine curve. Results were expressed as averages of 3 determinations \pm SD.

\section{Isolation and Purification of ACEI Peptides}

Ultrafitration. Samples were adjusted to $\mathrm{pH} 4.6$ (1 $M \mathrm{HCl})$ and centrifuged $(3,000 \times g$ for $20 \mathrm{~min})$. Supernatant (1) was readjusted to $\mathrm{pH} 7.0(1 \mathrm{M} \mathrm{NaOH})$ and centrifuged $(3,000 \times g$ for $10 \mathrm{~min})$, and supernatant (2) was collected. Supernatant (2) was readjusted to $\mathrm{pH}$ $8.3(1 \mathrm{M} \mathrm{NaOH})$ and centrifuged $(3,000 \times g$ for $5 \mathrm{~min})$. Supernatant (3) was subsequently stored at $-20^{\circ} \mathrm{C}$ for further analysis.

Each supernatant was filtered sequentially using an ultrafitration unit (Amicon Ultra $15 \mathrm{~mL}$, Millipore, Billerica, MA) using 2 membrane layers with molecular weight (MW) cutoffs of 3 and $10 \mathrm{kDa}$. The following 3 fractions were obtained: $\mathrm{MW}<3 \mathrm{kDa} ; 3 \mathrm{kDa}<\mathrm{MW}$ $<10 \mathrm{kDa}$; and MW $>10 \mathrm{kDa}$. The fraction with the highest ACEI activity was lyophilized and stored at 4 $\mathrm{C}^{\circ}$ for further purification.

Isolation and Purification of ACEI Peptides. Lyophilized samples $(1.5 \mathrm{~mL})$ were dissolved in deionized water (1:3) and loaded onto a Sephadex G-15 (Sigma-Aldrich) gel filtration column $(1.5 \mathrm{~cm} \times 50$ $\mathrm{cm})$. The column was subsequently eluted with distilled 
water at a flow rate of $0.3 \mathrm{~mL} / \mathrm{min} ; 1.5-\mathrm{mL}$ samples were collected.

The fraction $(100 \mu \mathrm{L})$ with the highest ACE inhibitory activity was separated using Thermo U3000 HPLC (Thermo Fisher Scientific Inc., Waltham, MA) at a flow rate of $1.0 \mathrm{~mL} / \mathrm{min}$ equipped with a $\mathrm{C} 18$ column $(4.6 \times 250 \mathrm{~mm}, 5 \mu \mathrm{m}$, Thermo Fisher Scientific Inc.). The elution system consisted of solution A, $0.05 \%$ (vol/ vol) trifluoroacetic acid (TFA) in 100\% (vol/vol) acetonitrile, and solution $\mathrm{B}, 0.05 \%$ (vol/vol) TFA in water. The linear gradient was used as follows (time, solvent A): 0 to $10 \mathrm{~min}, 0.05 \% \mathrm{~A} ; 10$ to $12 \mathrm{~min}, 0.05$ to $10 \% \mathrm{~A}$; 12 to $37 \mathrm{~min}, 10$ to $35 \% \mathrm{~A} ; 37$ to $38 \mathrm{~min}, 35$ to $100 \% \mathrm{~A}$; and 38 to $39 \mathrm{~min}$, and 100 to $0.05 \% \mathrm{~A}$. Elution peaks were monitored at $228 \mathrm{~nm}$. Amino acid sequences were determined on those fractions showing ACE activity.

\section{Identification of ACEI Peptides}

LC-MS/MS Analysis. The molecular mass and amino acid sequences of the purified peptides were determined by Orbitrap Elite liquid chromatography tandem mass spectrometry (LC-MS/MS) equipped with a C18 column $(1.8 \mu \mathrm{m}, 0.15 \times 100 \mathrm{~mm}$; Thermo Fisher Scientific Inc.). Elution A was prepared with $0.1 \%$ (vol/ vol) formic acid in water; elution B was 100\% (vol/vol) acetonitrile. The purified fraction $(1 \mu \mathrm{L})$ was spotted on a stainless steel target. The Orbitrap Elite LC-MS/ MS was run in the positive refractor mode, which covered a mass range of 350 to 1,000 Da, with an act time of $10 \mathrm{~ms}$ and a normalized collision energy of 35.0. The main peak, obtained after initial MS, was further analyzed using second MS. The amino acid sequence was determined using DeNovo Explorer software (AB Sciex, Framingham, MA) and confirmed using PEAKS 7.5 software (Bioinformatics Solutions Inc., Waterloo, ON, Canada).

Identification and Screening of the ACEI Peptides. The UniProt database (https://www.uniprot .org) was used to identify the ACEI peptides. The Expasy PeptideCutter tool was used to predict the cleavage site of a peptide sequence via 28 enzymes and chemicals (http://www.expasy.org/tools). The ACEI peptide sequences were compared with published polypeptide sequences in the AHTPDB database (http:/ /crdd.osdd.net/raghava/ahtpdb/) for verification purposes.

Fmoc Solid-Phase Synthesis of Peptides. Because extraction and isolation was both difficult and time consuming, we decided to synthesize the dipeptide Gly-Ala (GA). The GA had a high solubility in the $\mathrm{pH}$ range of 2 to 12 because of its structure, and the existence of the aliphatic branched-chain amino acid (Ala) made for the binding of GA to the active site of ACE (Wang et al., 2013), giving it superiority for application of blood pressure control foods. Shanghai Biotech BioScience and Technology Corp. (Shanghai, China) synthesized the identified ACEI peptide using an Fmoc solid-phase synthesis method (Schroder and Lubke, 1965). The purity of the peptide was $99.89 \%$, as determined by HPLC. The molecular mass was verified (147.3 Da) using electrospray ionization MS (API 150EX, AB Sciex) with a Kromasil 100-5 C18 column $(4.6 \mathrm{~mm} \times 250 \mathrm{~mm}, 5 \mu \mathrm{m}$, Thermo Fisher Scientific Inc.). The detection parameters were the same as the previous LC-MS/MS analysis of ACEI peptides.

\section{Characterization of ACEI Peptides}

Effects of $p H$ and Temperature on ACEI Activity. The ACEI peptide $(1.5 \mathrm{mg} / \mathrm{mL})$ was dissolved in deionized water and subsequently incubated for $2 \mathrm{~h}$ at $\mathrm{pH} 2,4,6,8,10$, and 12 . The $\mathrm{pH}$ of the solutions were then readjusted to $8.3(\mathrm{KCl}-\mathrm{NaOH}, \mathrm{KCl}$, and $\mathrm{HCl}$ buffers, $1.0 \mathrm{M}$ ), and the ACEI activity was determined. The peptide also was incubated for $2 \mathrm{~h}$ at 20, 40, 60, 80, and $100^{\circ} \mathrm{C}$. After acclimation to ambient temperature, the ACE activity was determined.

In Vitro Stability Digestion. Human gastrointestinal digestion was simulated according to the method used by Alvarado et al. (2019), with modifications. The chymotrypsin solution ( $1 \%$, wt $/ \mathrm{vol}, \geq 40$ units $/ \mathrm{mg}$ of protein) and trypsin solution ( $1 \%$, wt/vol, $\geq 6,000$

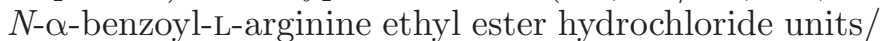
$\mathrm{mg}$ of protein) were adjusted to $\mathrm{pH} 8.3(1 \mathrm{M} \mathrm{NaOH})$, and the pepsin solution ( $1 \%$, wt $/ \mathrm{vol}, \geq 500 \mathrm{U} / \mathrm{mg}$ ) was dissolved in $1 \mathrm{M} \mathrm{KCl-HCl}$ buffer adjusted to $\mathrm{pH} 2.0$. The synthesized peptide $(1.5 \mathrm{mg} / \mathrm{mL})$ was added to the pepsin, chymotrypsin, and trypsin solutions for $3 \mathrm{~h}$ at $37^{\circ} \mathrm{C}$. The hydrolysates were centrifuged $(3,000 \times g$, $4^{\circ} \mathrm{C}$ ) for $15 \mathrm{~min}$; ACE activity was determined using a peptide concentration of $0.1 \mathrm{mg} / \mathrm{mL}$.

Antihypertensive Effects of $p H 4.6$ Extract. The research protocol was approved by the Animal Experimental Ethics Committee of the Inner Mongolia Agricultural University (Hohhot, China). To validate the antihypertensive effects of the $\mathrm{pH} 4.6$ extract, 18 spontaneously hypertensive rats (SHR; Beijing Weitong Lihua Experimental Animal Technology Co. Ltd., Beijing, China) were first divided into 3 groups [low-dose group, medium-dose group, and high-dose group $(\mathrm{n}=6)]$. After single intragastric doses $(5,10$, and $20 \mathrm{~mL} / \mathrm{kg}$ of rat weight) of the $\mathrm{pH} 4.6$ extract were administered, the medium-dose group had the best effect, and subsequent experiments were all performed by gavage of $10 \mathrm{~mL} / \mathrm{kg}$. To validate the antihypertensive effects of the $\mathrm{pH} 4.6$ extract, another 6 SHR rats and 6 Wistar rats with normal blood pressure (Beijing 


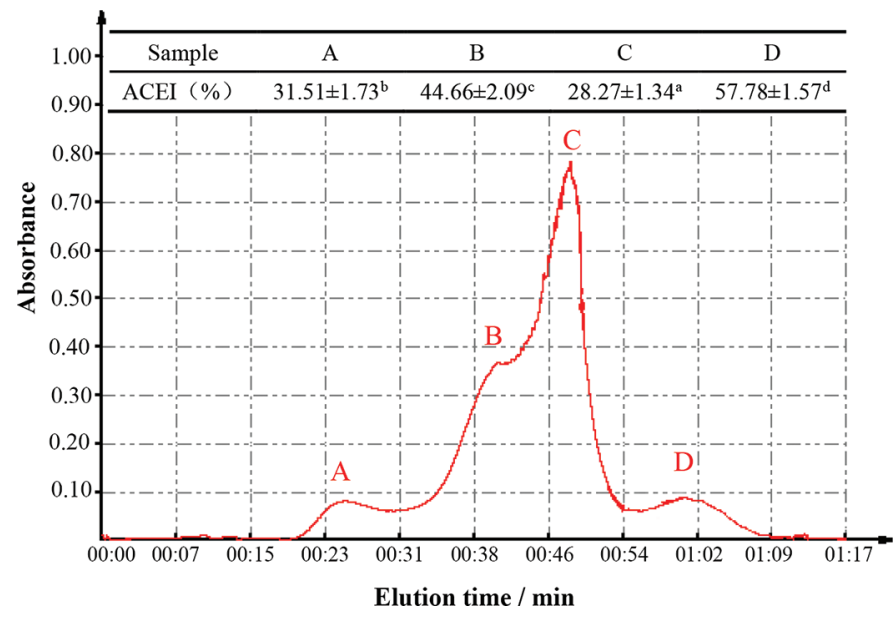

Figure 1. Sephadex G-15 (Sigma-Aldrich, St. Louis, MO) chromatogram of $\mathrm{pH} 4.6$ Lactobacillus plantarum milk extract. A, B, C, and $\mathrm{D}$ are the 4 major absorbance peaks at $228 \mathrm{~nm}$. Means with different lowercase letters $(\mathrm{a}-\mathrm{d})$ are significantly different $(P<0.05)$.

Weitong Lihua Experimental Animal Technology Co. Ltd.) and of the same age were administrated with the same amount of normal water and used as the model group and control group, respectively. Thereafter, longterm measurements applied to the experimental group, compared with the model group.

Single intragastric doses $(5,10$, and $20 \mathrm{~mL} / \mathrm{kg}$ of rat weight) were administered to the extract group; rats in the model and control groups were administrated the same amount of normal water. The blood pressure of the tail artery was measured by noninvasive blood pressure meter every $2 \mathrm{~h}$ for $10 \mathrm{~h}$. To evaluate long-term medication, a single dose of $10 \mathrm{~mL} / \mathrm{kg}$ was administered once a day over a 4 -wk period; blood pressure was monitored every week.

\section{Statistical Analyses}

Comparisons between ACEI activity of different fractions and blood pressure values of rats were analyzed using a one-way ANOVA, performed with SPSS 18.0 software (SPSS Inc., Chicago, IL). $P$-values $<0.05$ were considered significant. Standard deviations were also calculated and reported.

\section{RESULTS AND DISCUSSION}

\section{Isolation of ACEI Peptides}

The $\mathrm{pH}$ of the fermented milk was 4.5 after $48 \mathrm{~h}$ of fermentation. Results indicated that the ACEI of the fraction with $\mathrm{MW}<3 \mathrm{kDa}$ was $51.87 \pm 1.35 \%$, which was significantly $(P<0.05)$ higher than that of the fraction with $\mathrm{MW}>10 \mathrm{kDa}(21.58 \pm 1.42 \%)$ and the fraction with $3 \mathrm{kDa}<\mathrm{MW}<10 \mathrm{kDa}(38.38 \pm 1.44 \%)$. Accordingly, the fraction with MW $<3 \mathrm{kDa}$ was collected and freeze-dried after concentration.

Four peaks, A, B, C, and D, were collected after separation and purification via Sephadex g-15 (Figure 1); ACEI activity was evaluated at a concentration of $0.2 \mathrm{mg} / \mathrm{mL}$ (Table 1). Fraction D showed the highest ACEI activity $(57.78 \% \pm 1.57)$, followed by fraction B $(44.66 \% \pm 2.09)$, fraction $\mathrm{A}(31.51 \% \pm 1.73)$, and fraction $\mathrm{C}(28.27 \% \pm 1.34)$. The $\mathrm{IC}_{50}$ of ACEI of fraction D was $1.62 \mathrm{mg} / \mathrm{mL}$ (Table 2); it was further purified and analyzed using Orbitrap Elite LC-MS/MS.

\section{Purification of ACEI Peptides with RP-HPLC}

Reversed-phase (RP)-HPLC was used to purify fraction D. Four peaks were observed: $\mathrm{D}_{1}, \mathrm{D}_{2}, \mathrm{D}_{3}$, and $\mathrm{D}_{4}$

Table 1. Angiotensin-converting enzyme inhibitory (ACEI) activities of peptide segments during isolation and purification ${ }^{1}$

\begin{tabular}{llcc}
\hline Treatment $^{2}$ & Fraction & ACEI $(\%)$ & $\mathrm{IC}_{50}(\mathrm{mg} / \mathrm{mL})$ \\
\hline Sample & Fermented milk & $43.63 \pm 0.86^{\mathrm{c}}$ & $2.498 \pm 0.003^{\mathrm{b}}$ \\
Molecular membrane UF & $\mathrm{MW}>10 \mathrm{kDa}$ & $21.58 \pm 1.40^{\mathrm{a}}$ & $3.846 \pm 0.006^{\mathrm{c}}$ \\
& $3 \mathrm{kDa}<\mathrm{MW}<10 \mathrm{kDa}$ & $38.38 \pm 1.38^{\mathrm{b}}$ & $2.735 \pm 0.002^{\mathrm{d}}$ \\
Isolation by Sephadex G-15 & $\mathrm{MW}<3 \mathrm{kDa}$ & $51.87 \pm 1.35^{\mathrm{d}}$ & $1.998 \pm 0.004^{\mathrm{a}}$ \\
& $\mathrm{A}$ & $31.51 \pm 1.72^{\mathrm{b}}$ & $3.226 \pm 0.005^{\mathrm{c}}$ \\
& $\mathrm{B}$ & $44.66 \pm 2.09^{\mathrm{c}}$ & $2.436 \pm 0.008^{\mathrm{b}}$ \\
& $\mathrm{C}$ & $28.27 \pm 1.35^{\mathrm{a}}$ & $3.355 \pm 0.003^{\mathrm{d}}$ \\
Purification by RP-HPLC & $\mathrm{D}$ & $57.78 \pm 1.58^{\mathrm{d}}$ & $1.628 \pm 0.004^{\mathrm{a}}$ \\
& $\mathrm{D}_{1}$ & $63.71 \pm 0.55^{\mathrm{d}}$ & $1.247 \pm 0.001^{\mathrm{a}}$ \\
& $\mathrm{D}_{2}$ & $42.15 \pm 1.40^{\mathrm{c}}$ & $2.591 \pm 0.005^{\mathrm{b}}$ \\
& $\mathrm{D}_{3}$ & $27.35 \pm 1.34^{\mathrm{a}}$ & $3.417 \pm 0.003^{\mathrm{d}}$ \\
& $\mathrm{D}_{4}$ & $31.44 \pm 1.68^{\mathrm{b}}$ & $3.231 \pm 0.006^{\mathrm{c}}$ \\
\hline
\end{tabular}

${ }^{\mathrm{a}-\mathrm{d}}$ Means with different superscripts differ significantly $(P<0.05)$.

${ }^{1}$ Analyses were performed in triplicate. Values are means $\pm \mathrm{SD}$. $\mathrm{MW}=$ molecular weight; $\mathrm{IC}_{50}=$ median inhibitory concentration.

${ }^{2} \mathrm{UF}=$ ultrafiltration. Sephadex G-15: Sigma-Aldrich, St. Louis, MO. RP-HPLC = reversed-phase HPLC. 
Table 2. Blood pressure $(\mathrm{kPa})$ of spontaneously hypertensive rats (SHR) under different treatments of pH 4.6 Lactobacillus plantarum milk extract ${ }^{1}$

\begin{tabular}{|c|c|c|c|c|c|}
\hline \multirow[b]{2}{*}{ Time } & \multirow[b]{2}{*}{$\begin{array}{l}\text { Model } \\
\text { group }\end{array}$} & \multicolumn{3}{|c|}{ Experimental group } & \multirow[b]{2}{*}{$\begin{array}{l}\text { Control } \\
\text { group }\end{array}$} \\
\hline & & $\begin{array}{l}\text { Low-dose group } \\
\quad(5 \mathrm{~mL} / \mathrm{kg})\end{array}$ & $\begin{array}{l}\text { Medium-dose group } \\
\quad(10 \mathrm{~mL} / \mathrm{kg})\end{array}$ & $\begin{array}{l}\text { High-dose group } \\
\quad(20 \mathrm{~mL} / \mathrm{kg})\end{array}$ & \\
\hline \multicolumn{6}{|l|}{ Short-term (h) } \\
\hline 0 & $24.92 \pm 0.35$ & $25.24 \pm 0.68$ & $25.36 \pm 0.78$ & $25.23 \pm 0.69$ & $21.44 \pm 0.82$ \\
\hline 2 & $24.74 \pm 0.42$ & $24.81 \pm 0.57$ & $24.18 \pm 0.96$ & $23.44 \pm 1.14^{*}$ & $21.02 \pm 0.68$ \\
\hline 4 & $24.47 \pm 0.32$ & $24.40 \pm 0.61$ & $23.03 \pm 0.68^{*}$ & $22.98 \pm 0.98^{*}$ & $21.14 \pm 1.08$ \\
\hline 10 & $25.14 \pm 0.28$ & $25.23 \pm 0.98$ & $25.39 \pm 1.09$ & $25.36 \pm 0.64$ & $21.13 \pm 0.79$ \\
\hline \multicolumn{6}{|l|}{ Long-term ${ }^{2}$} \\
\hline Before gavage & $23.34 \pm 0.84$ & $23.58 \pm 0.62$ & & & \\
\hline Wk 1 & $25.26 \pm 0.94$ & $23.21 \pm 1.02$ & & & \\
\hline Wk 2 & $26.38 \pm 0.72$ & $22.75 \pm 0.78^{*}$ & & & \\
\hline Wk 3 & $28.34 \pm 0.56$ & $22.14 \pm 1.08^{*}$ & & & \\
\hline Wk 4 & $29.18 \pm 0.78$ & $21.72 \pm 0.95^{*}$ & & & \\
\hline
\end{tabular}

${ }^{1}$ Measurement of blood pressure were performed on 6 rats per group (model group, control group, and low-, medium-, and high-dose experimental groups). Values are mean $\pm \mathrm{SD}$. Single intragastric doses $(5,10$, and $20 \mathrm{~mL} / \mathrm{kg}$ rat weight) were administered in experimental groups; rats in model and control groups were administrated the same amount of normal water. Model group = SHR rats; control group = normal blood pressure Wistar rats.

${ }^{2}$ Long-term measurements apply to experimental group as a whole, compared with model group.

*Indicates significant difference compared with the blank control group $(P<0.05)$.

(Figure 2). The ACEI activities (\%) were: $63.71 \pm$ $0.56,42.15 \pm 1.42,27.35 \pm 1.36$, and $31.44 \pm 1.69$, respectively (Table 1 ). Fraction $\mathrm{D}_{1}$, which had the highest ACEI activity, exhibited an $\mathrm{IC}_{50}$ of $1.25 \mathrm{mg} / \mathrm{mL}$. This fraction was collected and lyophilized for further identification. Table 1 shows the ACEI activity under different separating conditions. The $\mathrm{IC}_{50}$ of the RPHPLC-purified fraction $\mathrm{D}_{1}$ was $49.9 \%$ that of the initial whey sample.

\section{Identification of ACEI Peptides}

Amino Acid Sequences of the Purified Peptides. Figure 3 shows the ion chromatogram of fraction $\mathrm{D}_{1}$. The relative molecular mass of the peptide was 146.16 Da. According to this molecular mass and the tandem MS results reported in Figures 3 and 4, the identified dipeptide was GA. According to the structure-activity relationship of ACEI peptides, ACE tends

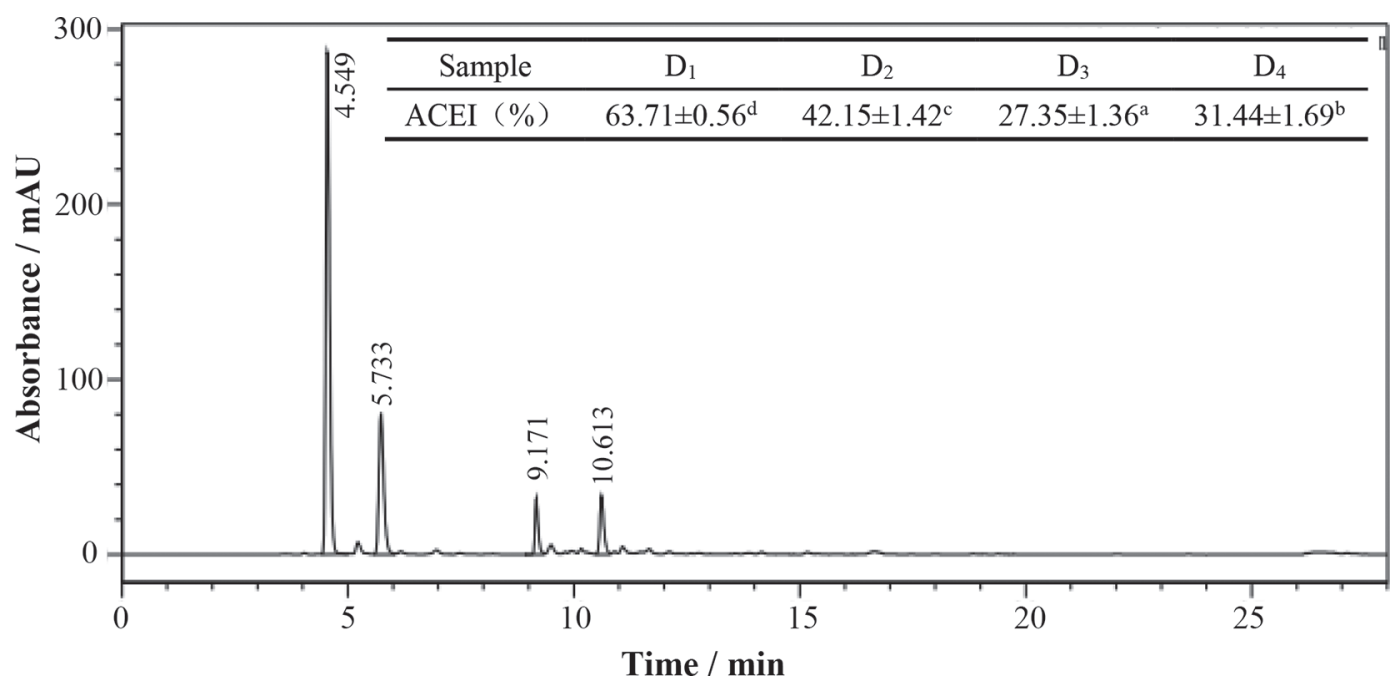

Figure 2. Reversed-phase high-performance liquid chromatography of fraction D and angiotensin-converting enzyme inhibitor (ACEI) activity of the chromatogram peaks. Means with different lowercase letters $(\mathrm{a}-\mathrm{d})$ are significantly different $(P<0.05)$. 
to bind substrates or competitive inhibitors with a Cterminal hydrophobic amino acid and an N-terminally aliphatic amino acid; the GA dipeptide isolated in this study meets these conditions (Ibrahim et al., 2017).

Compared with nonmilk sources, the ACEI activity of GA (63.71\%) was higher than that of ACEI activity of peptide (54\%) generated from porcine skeletal muscle proteins by the action of meat-borne Lactobacillus (Castellano et al., 2013). Wu et al. (2019) and Dabarera et al. (2015) isolated more efficient ACEI peptides from Lactobacillus delbrueckii QS306-fermented milk $(93.86 \%)$ and curd (96\%). Although ACEI activity of GA is not the most outstanding, its small size led to a low degree of intermolecular polymerization and extended molecular state, compared with the crimp state of macromolecular substance, giving the ACEI peptide GA good solubility. As a side benefit, the existence of the aliphatic branched-chain AA (Ala) is conducive to the binding of the peptide to the active site of $\mathrm{ACE}$ (Wang et al., 2013). This property is beneficial to its application in hypertension-control drugs and functional foods.

The UniProt database (https://www.uniprot.org) was used to compare the GA dipeptide with the protein sequence of milk. The possible sequence sources included $\alpha_{\mathrm{S} 1}-\mathrm{CN} \mathrm{f}(177-178)$, $\kappa$-CN f(20-21), $\beta$-LG f(13-14), and serum albumin $\mathrm{f}(198-199)$. The GA dipeptide and its associated ACEI activity were evaluated using the AHTPDB database (http://crdd.osdd.net/raghava/ ahtpdb/). The search revealed that the same peptide sequence was found in squid small albumin (Iwaniak and Dziuba, 2011), pork sarcoplasmic protein (Castellano et al., 2013), raw chicken muscle protein (Iwaniak and Dziuba, 2009), grain storage protein (Cavazos and Mejia, 2013), and milk protein (Iwaniak and Dziuba, 2009). Cheung et al. (1980) investigated the binding of peptide substrates and ACE inhibitors and found that the $\mathrm{IC}_{50}$ of synthetic GA was $2 \mathrm{~m} M$. In this study, the GA dipeptide was isolated and purified to determine its properties.

Properties and Stability of ACEI Peptide. The purity of the synthetic peptide was subsequently shown to be $99.89 \%$, with an $\mathrm{IC}_{50}$ of $1.22 \mathrm{mg} / \mathrm{mL}$, which was close to that of the isolated peptide $(1.25 \mathrm{mg} / \mathrm{mL})$. Because orally administered ACEI peptides need to retain activity following in vivo gastrointestinal enzyme digestion (Li et al., 2005; Balti et al., 2010), 3 gastrointestinal proteases (pepsin, chymotrypsin, and trypsin) were

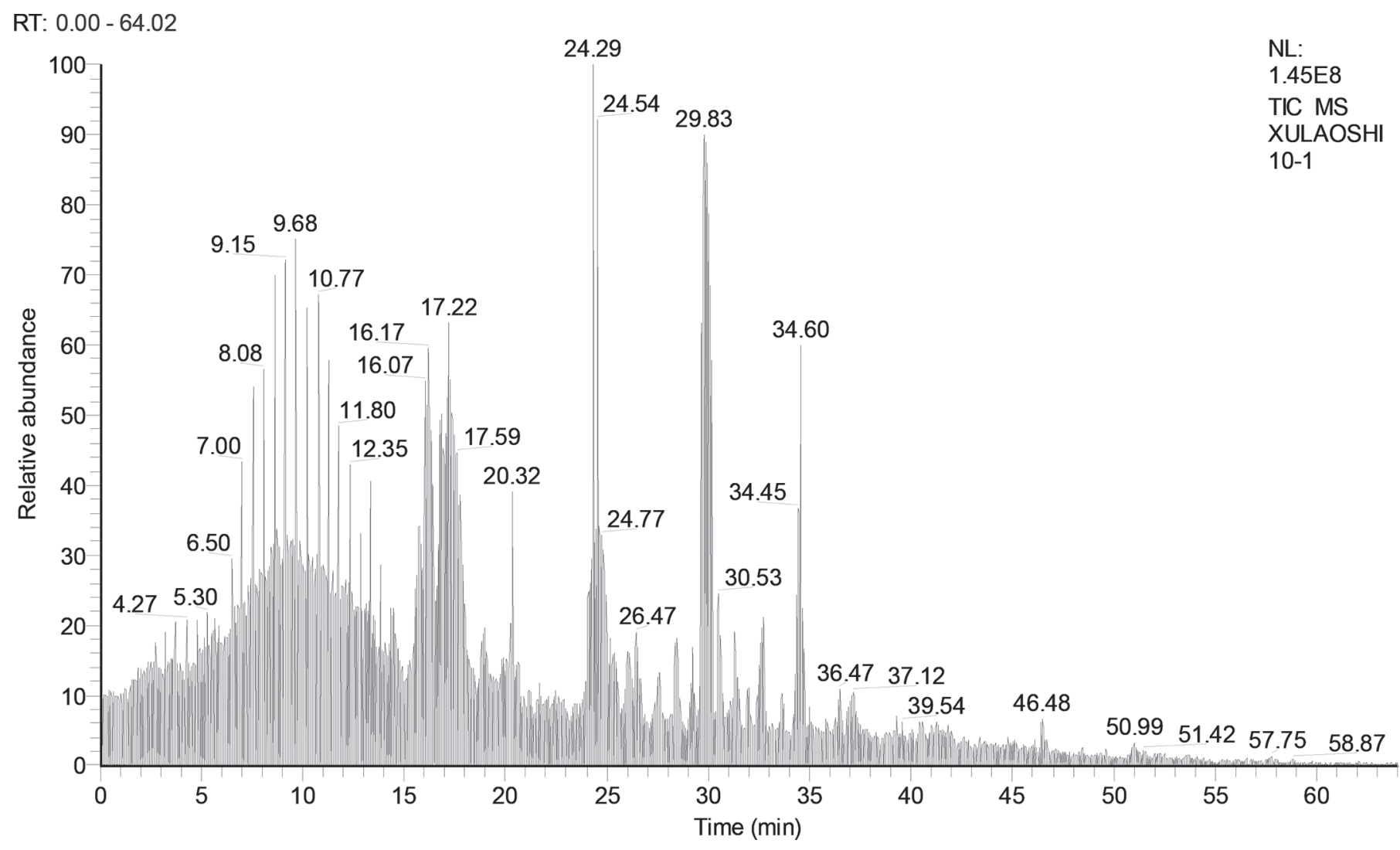

Figure 3. Ion chromatogram of purified angiotensin-converting enzyme-inhibition (ACEI) peptide $\mathrm{D}_{1}$ via Orbitrap Elite (Thermo Fisher Scientific Inc., Waltham, MA) liquid chromatography-tandem mass spectrometry. 
(A)

XULAOSHI10-1 \#5814 RT: 30.10 AV: 1 NL: 3.06E7

T: FTMS + p NSI Full ms [50.00-1000.00]

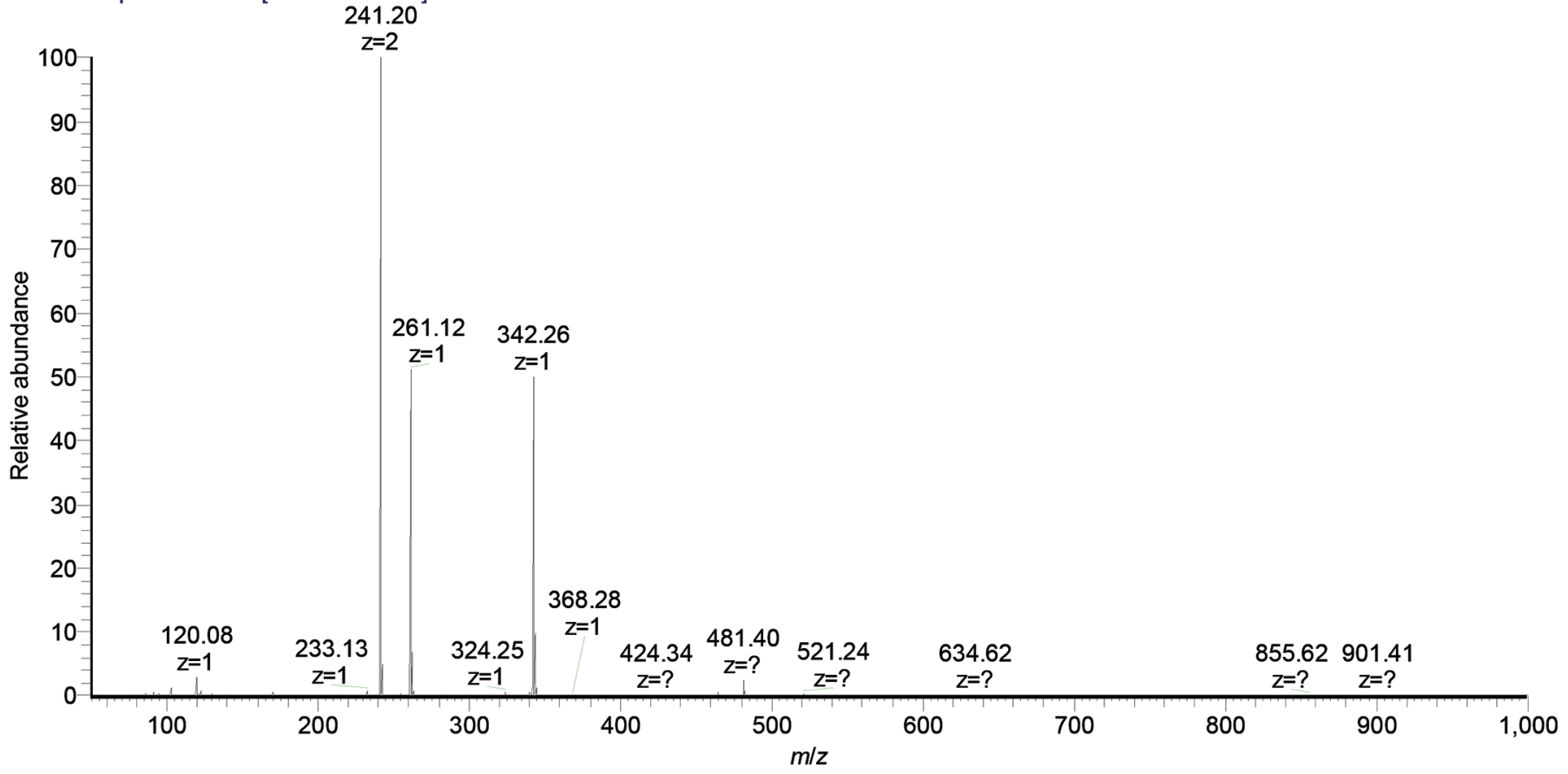

(B)

XULAOSHI10-1 \#491 RT: 2.56 AV: 1 NL: $1.20 E 5$

F: FTMS + c NSI d Full ms2 147.04@hcd35.00 [50.00-160.00]

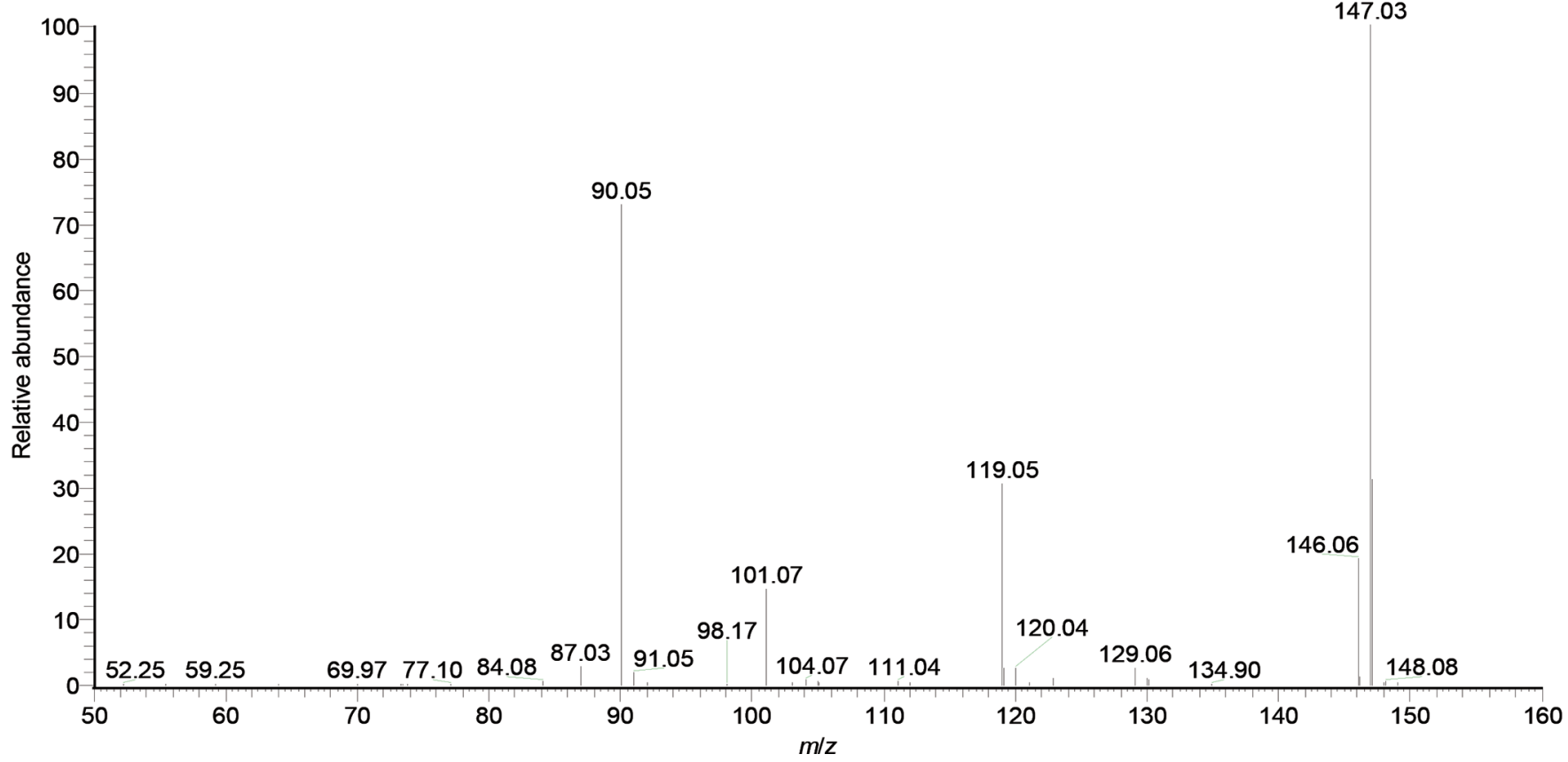

Figure 4. Mass spectrometry (A) and tandem mass spectrometry (MS/MS, B) of angiotensin-converting enzyme-inhibition (ACEI) peptide $\mathrm{D}_{1}$ via Orbitrap Elite (Thermo Fisher Scientific Inc., Waltham, MA) liquid chromatography (LC)-MS/MS. 
used in turn to digest GA, in the order in which food is actually digested in the gastrointestinal tract. We found that ACEI activity gradually decreased throughout progressive digestion stages (Figure 5a) but remained at a high level (50\%) after trypsin treatment, compared with the control group [nontreated GA (64.3\%)], suggesting that the GA dipeptide may have some in vivo stability suitable for human use. The reduction in ACEI activity was due to hydrolysis of a small part of the polypeptide by gastrointestinal enzymes. Similar results were found in the ACE inhibitory rates of pupa ACEIP $\alpha-P 3-6-b$, which was significantly $(P<0.05)$ reduced by $9.21 \%$ after hydrolysis using pepsin ( $\mathrm{Li}$ et al., 2014). A case in which ACEI activity increased after gastrointestinal enzyme treatment also occurred in a pentapeptide (LPYPY) isolated and identified from milk fermented using Lactobacillus delbrueckii QS306 (Wu et al., 2019).

During their processing and transit through the gastrointestinal tract, ACEI peptides encounter different $\mathrm{pH}$ and temperature levels, so it is essential to test their stability under these conditions. Exposure to $\mathrm{pH}$ from 2 to 12 and temperatures 20 to $60^{\circ} \mathrm{C}$ did not change the inhibitory activity of the GA (Figure 5b and $\mathrm{c}$ ), indicating that the ACEI activity was stable to a certain extent. However, GA exposure above $80^{\circ} \mathrm{C}$ is not recommended, because high temperatures may accelerate cleavage of the peptide chain so that ACEI activity would be affected. Many reports show similar performance. Hwang (2010) and Li et al. (2018) confirmed that the ACEI peptides from tuna and black soybean sources were stable in the range of $\mathrm{pH} 2$ to approximately 10. However, the ACEI activity of the peptide WPMGF, derived from enzymatic hydrolysates of Cyclina sinensis, decreased slightly in strongly acidic and alkaline environments $(\mathrm{pH} 2,4,10,12)$ and remained stable after exposure to a weakly acid ( $\mathrm{pH} 6)$ or base ( $\mathrm{pH} 8)$ environment, compared with $\mathrm{pH} 7(\mathrm{Yu}$ et al., 2018). A peptide derived from duck meat hydrolysate attained its highest activity at $\mathrm{pH} 7$ and sharply declined under alkaline conditions, indicating that each peptide has its ideal $\mathrm{pH}$ range, in which the structure and activity of the peptide are relatively stable (Shi et al., 2019). Thermal treatment appears to have a greater effect on peptide activity. Activity of a peptide isolated and purified from Spanish dry-cured ham slightly decreased when the temperature was higher than $50^{\circ} \mathrm{C}$ (Escudero et al., 2014). Li et al. (2018) found that higher temperatures (above $40^{\circ} \mathrm{C}$ ) did decrease the ACEI activity, with only $33 \%$ of the ACE activity inhibited at $100^{\circ} \mathrm{C}$ because of the increase of the cleavage and degradation of black soybean peptides. Yu et al. (2018) confirmed that lower temperatures also decreased the
ACEI activity of the peptide WPMGF, reaching only $46 \%$ at $0^{\circ} \mathrm{C}$. These reports indicate that most peptides are stable when the temperature remains at or above body temperature, which is desirable for the industrial production of antihypertensive functional foods.
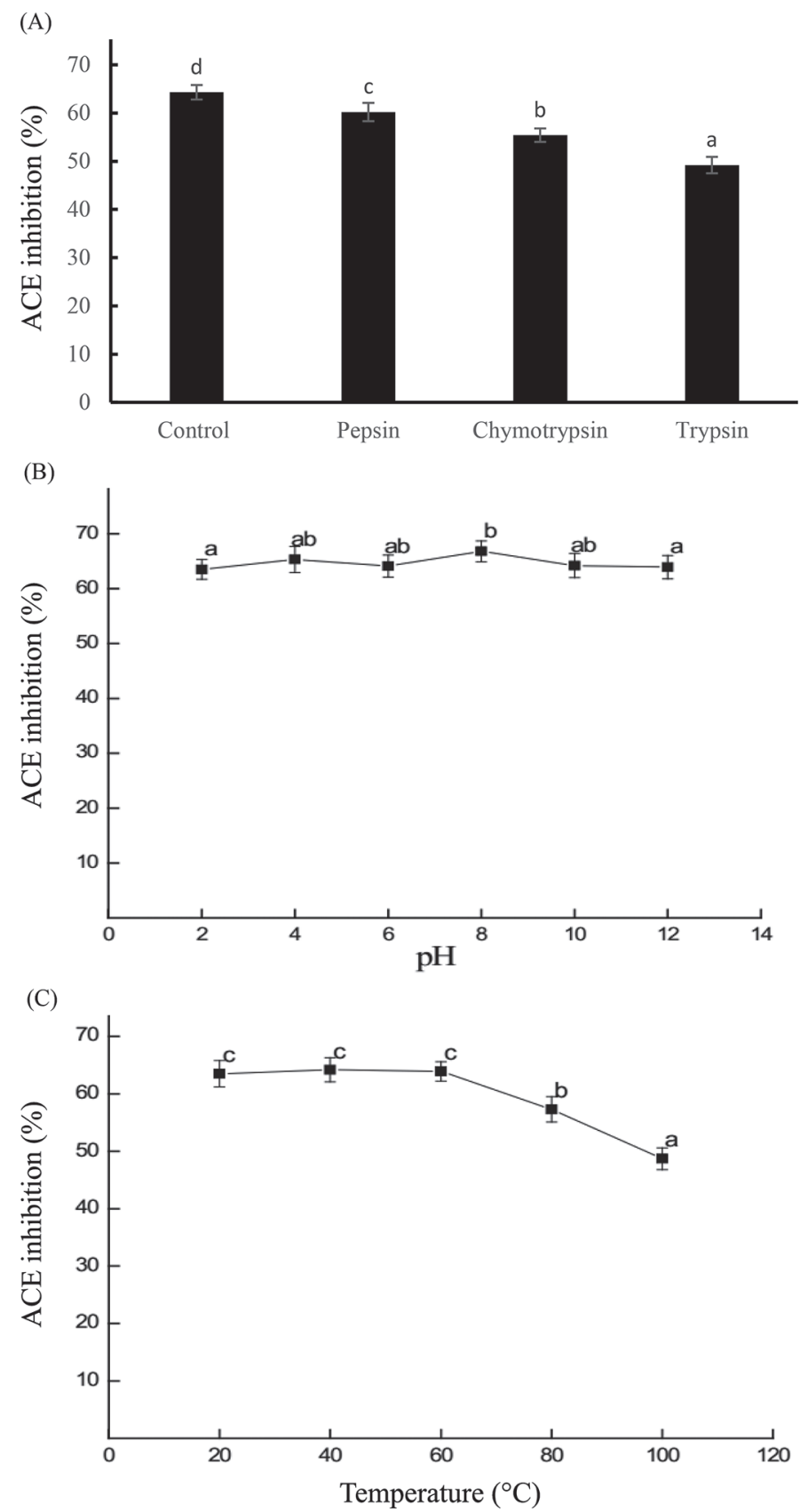

Figure 5. Angiotensin-converting enzyme inhibition (ACEI) activity of synthetic peptide Gly-Ala (GA) after treatment by gastrointestinal enzymes (A), pH (B), and temperature (C). Control group $=$ nontreated GA. Means with different lowercase letters $(\mathrm{a}-\mathrm{d})$ are significantly different $(P<0.05)$. Error bars represent SE. 


\section{Antihypertensive Effects of pH 4.6 Extract}

As shown in Table 2, blood pressure in the low-dose group $(5 \mathrm{~mL} / \mathrm{kg})$ of SHR rats decreased slightly, and an antihypertensive effect was not evident. The medium- $(10 \mathrm{~mL} / \mathrm{kg})$ and high-dose groups $(20 \mathrm{~mL} / \mathrm{kg})$ reduced the blood pressure to $23.03 \mathrm{kPa} \pm 0.68$ and $22.98 \mathrm{kPa} \pm 0.98$ at $4 \mathrm{~h}$, getting the effect of lowering blood pressure within $8 \mathrm{~h}$, and recovered to 25.39 $\mathrm{kPa} \pm 1.09$ and $25.36 \mathrm{kPa} \pm 0.64$ at $10 \mathrm{~h}$ respectively, $100.11 \%$ and $100.51 \%$ of the original blood pressure $(25.36 \mathrm{kPa} \pm 0.78,25.23 \mathrm{kPa} \pm 0.69)$. Although the effect of lowering blood pressure in the high-dose group was obvious, the rapid decrease and recovery of blood pressure could have deleterious effects on the heart. In this investigation, a dose of $10 \mathrm{~mL} / \mathrm{kg}$ was chosen as the best overall, exerting a pressure drop of 2.33 $\mathrm{kPa}$. Long-term experiments were therefore conducted with this dose. Overall, the blood pressure of SHR rats administered GA was lower than that of the control group. Overall, the blood pressure of SHR rats administered GA was lower than that of the model group. After $4 \mathrm{wk}$, the blood pressure of the SHR rats decreased $1.86 \mathrm{kPa}, 7.46 \mathrm{kPa}$ lower than that of the model group, suggesting that continuous gavage using $\mathrm{pH} 4.6$ extract could control blood pressure and maintain blood pressure stability. Continuous gavage could therefore mimic everyday consumption of the fermented product by humans who need to control blood pressure. A unique peptide in fermented dairy products, GA could be used as an ingredient in future functional foods to prevent chronic diseases. How GA lowers blood pressure in vivo needs to be further investigated.

\section{CONCLUSIONS}

The GA peptides produced during fermentation of cow milk using Lb. plantarum QS670 were isolated and purified by size-exclusion chromatography, RPHPLC, and LC-MS/MS. The peptides had an $\mathrm{IC}_{50}$ of $1.26 \mathrm{mg} / \mathrm{mL}$. Although initially found in fermented whey samples, GA may have been derived from $\alpha_{S^{-}}$ CN $\mathrm{f}(177-178), \kappa-\mathrm{CN} \mathrm{f}(20-21), \beta-\mathrm{LG} \mathrm{f}(13-14)$, and serum albumin $\mathrm{f}(198-199)$. Subsequently the Gly-Ala dipeptide was synthesized using an Fmoc solid-phase method; it had purity of $99.9 \%$ and an $\mathrm{IC}_{50}$ of $1.22 \mathrm{mg} /$ $\mathrm{mL}$. The peptide exhibited stability over a temperature range of 20 to $60^{\circ} \mathrm{C}$ and $\mathrm{pH} 2$ to 12 . It also exhibited stability toward chymotrypsin, pepsin, and trypsin. The $\mathrm{pH} 4.6$ extract exhibited a blood pressure drop of $2.33 \mathrm{kPa}$ when fed to SHR rats compared with pregavage state; long-term gavage treatment augmented the hypotensive effect, with a decrease in pressure of $7.46 \mathrm{kPa}$. These results suggest that milk fermented with Lb. plantarum QS670 is a potential source of ACEI peptides that could be used in the making of hypotensive products.

\section{ACKNOWLEDGMENTS}

This work was supported by the National Natural Science Foundation of China (Beijing; Grant No. 31460443), the Municipality Technology Support Project of Inner Mongolia (Hohhot, China; Grant No. KCBJ2018011) and the Excellent Doctoral Research Project of Inner Mongolia Agricultural University (Hohhot, China; NDYB2018-45). The authors declare no conflict of interest.

\section{REFERENCES}

Alvarado, Y., C. Muro, J. Illescas, M. D. Diaz, and F. Riera. 2019. Encapsulation of antihypertensive peptides from whey proteins and their releasing in gastrointestinal conditions. Biomolecules 9:E164. https://doi.org/10.3390/biom9050164.

Balti, R., N. Nedjar-Arroume, A. Bougatef, D. Guillochon, and M. Nasri. 2010. Three novel angiotensin I-converting enzyme (ACE) inhibitory peptides from cuttlefish (Sepia officinalis) using digestive proteases. Food Res. Int. 43:1136-1143. https://doi.org/10 .1016/j.foodres.2010.02.013.

Castellano, P., M. C. Aristoy, M. Á. Sentandreu, G. Vignolo, and F. Toldrá. 2013. Peptides with angiotensin I converting enzyme (ACE) inhibitory activity generated from porcine skeletal muscle proteins by the action of meat-borne Lactobacillus. J. Proteomics 89:183-190. https://doi.org/10.1016/j.jprot.2013.06.023.

Cavazos, A., and E. Gonzalez de Mejia. 2013. Identification of bioactive peptides from cereal storage proteins and their potential role in prevention of chronic diseases. Compr. Rev. Food Sci. Food Saf. 12:364-380. https://doi.org/10.1111/1541-4337.12017.

Chaves-López, C., A. Serio, A. Paparella, M. Martuscelli, A. Corsetti, R. Tofalo, and G. Suzzi. 2014. Impact of microbial cultures on proteolysis and release of bioactive peptides in fermented milk. Food Microbiol. 42:117-121. https://doi.org/10.1016/j.fm.2014.03.005.

Cheung, H. S., F. L. Wang, M. A. Ondetti, E. F. Sabo, and D. W. Cushman. 1980. Binding of peptide substrates and inhibitors of angiotensin-converting enzyme. J. Biol. Chem. 255:401-407.

Cushman, D. W., and H. S. Cheung. 1971. Spectrophotometric assay and properties of the angiotensin-converting enzyme of rabbit lung. Biochem. Pharmacol. 20:1637-1648. https://doi.org/10 .1016/0006-2952(71)90292-9.

Dabarera, M. C., L. V. Athiththan, and R. P. Perera. 2015. Antihypertensive peptides from curd. Ayu 36:214-219. https://doi.org/ 10.4103/0974-8520.175534.

Daliri, E. B. M., B. H. Lee, M. H. Park, J. H. Kim, and D. H. Oh. 2018. Novel angiotensin I-converting enzyme inhibitory peptides from soybean protein isolates fermented by Pediococcus pentosaceus SDL1409. Lebensm. Wiss. Technol. 93:88-93. https://doi .org/10.1016/j.lwt.2018.03.026.

Ehlers, M. R., and J. F. Riordan. 1989. Angiotensin-converting enzyme: New concepts concerning its biological role. Biochemistry 28:5311-5318. https://doi.org/10.1021/bi00439a001.

Escudero, E., L. Mora, and F. Toldrá. 2014. Stability of ACE inhibitory ham peptides against heat treatment and in vitro digestion. Food Chem. 161:305-311. https://doi.org/10.1016/j.foodchem .2014.03.117.

Esmaeili, S. A., M. Mahmoudi, Z. Rezaieyazdi, M. Sahebari, N. Tabasi, A. Sahebkar, and M. Rastin. 2018. Generation of tolerogenic dendritic cells using Lactobacillus rhamnosus and Lactobacillus delbrueckii as tolerogenic probiotics. J. Cell. Biochem. 119:7865-7872. https://doi.org/10.1002/jcb.27203. 
Galli, B. D., D. P. Baptista, F. G. Cavalheiro, F. Negrão, M. N. Eberlin, and M. L. Gigante. 2019. Peptide profile of Camembert-type cheese: Effect of heat treatment and adjunct culture Lactobacillus rhamnosus GG. Food Res. Int. 123:393-402. https://doi.org/10 .1016/j.foodres.2019.05.009.

Hwang, J. S. 2010. Impact of processing on stability of angiotensin Iconverting enzyme (ACE) inhibitory peptides obtained from tuna cooking juice. Food Res. Int. 43:902-906. https://doi.org/10.1016/ j.foodres.2009.12.012

Ibrahim, H. R., A. S. Ahmed, and T. Miyata. 2017. Novel angiotensinconverting enzyme inhibitory peptides from caseins and whey proteins of goat milk. J. Adv. Res. 8:63-71. https://doi.org/10.1016/ j.jare.2016.12.002.

Iwaniak, A., and J. Dziuba. 2009. Animal and plant proteins as precursors of peptides with ACE inhibitory activity-An in silico strategy of protein evaluation. Food Technol. Biotechnol. 47:441-449.

Iwaniak, A., and J. Dziuba. 2011. BIOPEP-PBIL tool for the analysis of the structure of biologically active motifs derived from food proteins. Food Technol. Biotechnol. 49:118-127.

Kumar, N., and C. Yin. 2018. The anti-inflammatory peptide Ac-SDKP: Synthesis, role in ACE inhibition, and its therapeutic potential in hypertension and cardiovascular diseases. Pharmacol. Res. 134:268-279. https://doi.org/10.1016/j.phrs.2018.07.006.

Li, G. H., G. W. Le, H. Liu, and Y. H. Shi. 2005. Mung-bean protein hydrolysates obtained with Alcalase exhibit angiotensin I-converting enzyme inhibitory activity. Food Sci. Technol. Int. 11:281-287. https://doi.org/10.1177/1082013205056781.

Li, M., S. Xia, Y. Zhang, and X. Li. 2018. Optimization of ACE inhibitory peptides from black soybean by microwave-assisted enzymatic method and study on its stability. Lebensm. Wiss. Technol. 98:358-365. https://doi.org/10.1016/j.lwt.2018.08.045.

Li, X., Y. Li, X. Huang, J. Zheng, F. Zhang, and J. Kan. 2014. Identification and characterization of a novel angiotensin I-converting enzyme inhibitory peptide (ACEIP) from silkworm pupa. Food Sci. Biotechnol. 23:1017-1023. https://doi.org/10.1007/s10068-014 -0138-9.

Minervini, F., F. Algaron, C. G. Rizzello, P. F. Fox, V. Monnet, and A. Gobbetti. 2003. Angiotensin I-converting-enzyme-inhibitory and antibacterial peptides from Lactobacillus helveticus PR4 proteinase-hydrolyzed caseins of milk from six species. Appl. Environ. Microbiol. 69:5297-5305. https://doi.org/10.1128/AEM.69.9.5297 -5305.2003 .

Nakamura, Y., N. Yamamoto, K. Sakai, and T. Takano. 1995. Antihypertensive effect of sour milk and peptides isolated from it that are inhibitors to angiotensin I-converting enzyme. J. Dairy Sci. 78:1253-1257. https://doi.org/10.3168/jds.S0022-0302(95)76745 -5 .

Schroder, E., and K. Lubke. 1965 Solid phase peptide synthesis. Pages 317-318 in Methods of Peptide Synthesis. Academic Press, Amsterdam, the Netherlands. https://doi.org/10.1016/B978-1-4832 $-2819-8.50015-5$

Seppo, L., T. T. Jauhiainen, T. Poussa, and R. Korpela. 2003. A fermented milk high in bioactive peptides has a blood pressure-lowering effect in hypertensive subjects. Am. J. Clin. Nutr. 77:326-330. https://doi.org/10.1093/ajcn/77.2.326.

Shi, C., T. Li, J. Huang, I. A. Khan, M. Huang, and G. Zhou. 2019. Effect of processing conditions and simulated gastrointestinal di- gestion on the activity of angiotensin I-converting enzyme (ACE) inhibitory peptide derived from duck meat hydrolysate. CYTA J. Food 17:393-399. https://doi.org/10.1080/19476337.2019.1575909.

Shuang, Q., W. Xu, J. Han, and N. Wu. 2017. Antihypertensive effects of yogurt fermented with Lactobacillus plantarum QS670 in spontaneously hypertensive rats. Food. Res. Developm. 38:181-184.

Timón, M. L., A. I. Andres, J. Otte, and M. J. Petron. 2019. Antioxidant peptides $(<3 \mathrm{kDa})$ identified on hard cow milk cheese with rennet from different origin. Food Res. Int. 120:643-649. https:// doi.org/10.1016/j.foodres.2018.11.019.

Tsai, J. S., Y. S. Lin, B. S. Pan, and T. J. Chen. 2006. Antihypertensive peptides and $\gamma$-aminobutyric acid from prozyme 6 facilitated lactic acid bacteria fermentation of soymilk. Process Biochem. 41:1282-1288. https://doi.org/10.1016/j.procbio.2005.12.026.

Usui, Y., Y. Kimura, T. Satoh, N. Takemura, Y. Ouchi, H. Ohmiya, K. Kobayashi, H. Suzuki, S. Koyama, S. Hagiwara, H. Tanaka, S. Imoto, G. Eberl, Y. Asami, K. Fujimoto, and S. Uematsu. 2018. Effects of long-term intake of a yogurt fermented with Lactobacillus delbrueckii ssp. bulgaricus 2038 and Streptococcus thermophilus 1131 on mice. Int. Immunol. 30:319-331. https://doi.org/10.1093/ intimm/dxy035.

Wang, Q., C. Wang, H. Hu, H. Liu, and L. Liu. 2013. Structural characterization and structure-activity relationship of ACE inhibitory peptides from peanut. Food. Sci. (China) 34:170-174.

Wu, N., W. H. Xu, K. L. Liu, Y. N. Xia, and Shuangquan.. 2019. Angiotensin-converting enzyme inhibitory peptides from Lactobacillus delbrueckii QS306 fermented milk. J. Dairy Sci. 102:5913-5921. https://doi.org/10.3168/jds.2018-15901.

Yang, G., Y. Jiang, W. Yang, F. Du, Y. Yao, C. Shi, and C. Wang. 2015. Effective treatment of hypertension by recombinant Lactobacillus plantarum expressing angiotensin converting enzyme inhibitory peptide. Microb. Cell Fact. 14:202. https://doi.org/10.1186/ s12934-015-0394-2.

Yu, F., Z. Zhang, L. Luo, J. Zhu, F. Huang, Z. Yang, Y. Tang, and G. Ding. 2018. Identification and molecular docking study of a novel angiotensin-I converting enzyme inhibitory peptide derived from enzymatic hydrolysates of Cyclina sinensis. Mar. Drugs 16:E411. https://doi.org/10.3390/md16110411.

Zafari, N., S. Asgari, M. Lotfaliany, A. Hadaegh, F. Azizi, and F. Hadaegh. 2017. Impact of hypertension versus diabetes on cardiovascular and all-cause mortality in Iranian older adults: Results of 14 years of follow-up. Sci. Rep. 7:14220. https://doi.org/10.1038/ s41598-017-14631-2.

Zhao, Y. Q., L. Zhang, J. Tao, C. F. Chi, and B. Wang. 2019. Eight antihypertensive peptides from the protein hydrolysate of Antarctic krill (Euphausia superba): Isolation, identification, and activity evaluation on human umbilical vein endothelial cells (HUVECs). Food Res. Int. 121:197-204. https://doi.org/10.1016/j.foodres .2019.03.035.

\section{ORCIDS}

Weihan Xu (i) https://orcid.org/0000-0002-5738-4274

Quan Shuang ๑ https://orcid.org/0000-0002-0827-7384 